\title{
Historical Case Report: 45 Years of the First Plastic Surgery in Morbid Obese in Brazil and Their Weight Loss
}

\author{
José Humberto Cardoso Resende ${ }^{1}$, Cristine Mara Fragoso Dos Santos Oliveira², \\ Heitor Dos Santos Leão², Bruno Viana Martins'², Brenda Martins Fernandes², \\ Valentina Ruvieri Silveira², Juliana Araújo Naves², Ítalo Julierme Barros Duarte², \\ Emídio Silva Falcão Brasileiro ${ }^{3}$
}

\author{
${ }^{1}$ UNIFAN, Coordinator of the Work, Aparecida de Goiânia, Brazil \\ ${ }^{2}$ UNIFAN, Academics of Medicine, Aparecida de Goiânia, Brazil \\ ${ }^{3}$ UNIFAN, Coordinator of Research, Aparecida de Goiânia, Brazil \\ Email: jresen99@hotmail.com
}

How to cite this paper: Resende, J.H.C., Oliveira, C.M.F.S., Leão, H.S., Martins, B.V., Fernandes, B.M., Silveira, V.R., Naves, J.A., Duarte, Í.J.B. and Brasileiro, E.S.F. (2020) Historical Case Report: 45 Years of the First Plastic Surgery in Morbid Obese in Brazil and Their Weight Loss. Modern Plastic Surgery, 10, 82-92.

https://doi.org/10.4236/mps.2020.103010

Received: May 15, 2020

Accepted: July 6, 2020

Published: July 9, 2020

Copyright $\odot 2020$ by author(s) and Scientific Research Publishing Inc. This work is licensed under the Creative Commons Attribution International License (CC BY 4.0).

http://creativecommons.org/licenses/by/4.0/

\begin{abstract}
Before the 70s, in Brazil, each city had its morbidly obese, considered as the "excessive fats", in very small numbers if we compare it with the current percentage. There was no classification of the degree of obesity by the body mass index (BMI) as we have today. By chance, on a Saturday in June 1975, at the Outpatient Clinic of the 23rd Infirmary of Santa Casa da Misericórdia Hospital in Rio de Janeiro, arrived the patient I. S., 41 years old, $1.70 \mathrm{~m}$ tall, supported by her two children, weighing $210 \mathrm{~kg}$ in weight body. Knowing that bariatric surgery only appeared in the 1980s, before that, patients with morbid obesity were left to their own devices, with hypertension and diabetes. The patient I. S. was hospitalized for 3 years in our Plastic Surgery Service, having received nutritional monitoring, had sporadic discharges and undergone 9 reparative plastic surgeries. She was discharged weighing $71 \mathrm{~kg}$, with self-esteem recovered and happy to start a new life, without hypertension and diabetes.
\end{abstract}

\section{Keywords}

Obesity, Hypertension, Diabetes, Plastic Surgery, Slimming

\section{Introduction}

This manuscript will serve to guide future doctors who will be able to deepen their studies on this disease called OBESITY. After 45 years of the first plastic 
surgery in morbidly obese in Brazil, we thought it was a good idea to honor the colleagues who were present during this time of tireless professional work at the Santa Casa da Misericórdia Hospital in Rio de Janeiro, Brazil. This was the first step before we founded the Chapter of Plastic Surgery in Obesity at the Brazilian Society of Plastic Surgery and, later, we implemented the "Obese Workshop" at the Federal Hospital of Servers of the State of Rio de Janeiro.

We know that subsistence and nourishment are our source of life. During the medical career, we learned that this is a pathology that kills if it is not treated in time. Morbid obesity involves, in addition to overeating, a lack of physical exercise, which causes numerous disorders resulting from hypertension and diabetes, and affects the psychological and social sector of patients. Due to bodily deformity and the difficulties of mobilization, they remain in a form of servitude all the time, which prevents them from enjoying life's pleasures, gradually causing paralysis, as shown in this career first case (Figure 1). The constraints, according to Scherer (2012) [1], and the upsets caused by the disease, leave the patient without opportunities in the world. For countless reasons, we know that there are no job opportunities for the morbidly obese. Thus, we consider this disease to be a public health problem [2]. Words banned by the disease: thinness, elegance, health, happiness, relationships, joys, in addition to the ban on coming and going. There are no spaces in the chairs of cinemas and theaters, buses, stretchers in hospitals, bathrooms, airplanes, all due to the lack of attention from public agencies. Even struggling a lot, sending projects, we were unable to fulfill the dream of an appropriate hospital for $40 \%$ of the overweight population and $10 \%$ of morbidly obese people. What values are being developed in the current "Society"? (Carvalho, 2010) [3].

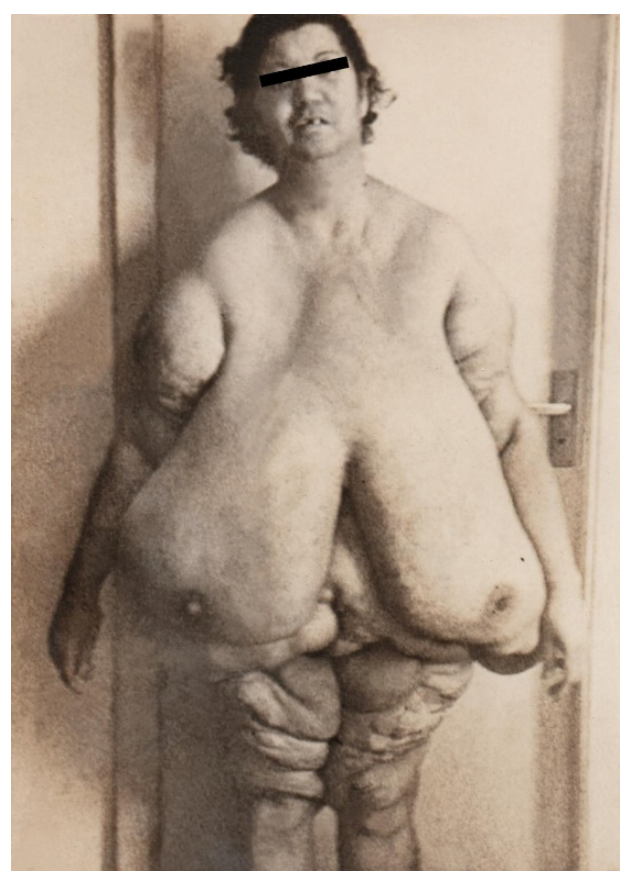

Figure 1. 1st day of hospitalization. 
They are considered disabled (Medeiros, 2018) [4] in some tasks and cannot exercise their rights equally to the slender. In the case reported, we admitted for philanthropic reasons, even without future planning. The patient said: "Doctor, you saw me, be the mechanic, I'm in the workshop". On the following Monday, with the authorization of Prof. Xavier Lopes, we started to create a nutritional and surgical protocol to attend to her. We are very grateful to our head nurse, the Dominican Sister Lúcia Sezures, who was the right hand in this period. One day, she said: "Doctor, don't worry, the food here is so bad that the patient will lose weight anyway". I had already finished my 2 -year residency in general surgery and was in the second year of plastic surgery. We idealize performing body relief surgeries concomitantly with weight loss using protein and vitamin supplements every 6 hours [5]. The largest surgical piece excised was the breasts with $32 \mathrm{~kg}$. All laboratory tests of the patient, upon admission, were altered, including blood pressure and blood glucose, $170 \times 110 \mathrm{mmHg}$ and $210 \mathrm{mg} / \mathrm{dL}$, respectively. Although obese, she had a $34 \%$ hematocrit.

We felt compelled to remember in honor of the courageous team that helped us at a time when everything was new and undergoinga learning stage. Anesthetists: Dr. Kleber Sardenberg (RJ), Dr. Marcos Botelho (RJ) and Dr. Marco Antonio Garambone (RJ); Surgeon: Dr. José Humberto Cardoso Resende (RJ); Assistants: Dr. Elmo Glória Filho (RJ), Dr. Hermes Galvão de Sá Filho (PB), Dr. Zeneide Alves de Souza (AP); Nurse: Sister Lúcia Sezures; Location: 23rd Infirmary of Santa Casa da Misericórdia Hospital in Rio de Janeiro.

\section{Material}

45 years ago, it was not usual to document the pre and postoperative surgeries. If there was any kind of lawsuit, which was rare, black and white photos were accepted. At that time, we used the old "slides"-slides (sheets) of an image projector presentation. Even so, we are amazed to have kept and organized, at least, the main results of the reparative surgeries that, today, I call "body relief".

After some Plastic Surgery Services rejected the lady I. S.'s case, I took courage and made a plan that I thought was more adapted to what I knew. A careful pre-operative, which I follow to this day, and the most important: to not put the patient's life at risk. Nutrition was controlled with protein and vitamin supplements [6]. After she lost $20 \mathrm{~kg}$ in 6 months, we checked her laboratory exams, which would allow us to start surgery. All results were already within normal limits. We decided to do only one body part at a time, a technique recommended until today [7]. Then, in the 6th month, we marked the extirpation of the larger part, the breasts (Figure 2), which had two layers of tissue, skin and subcutaneous cell, never seen before in professional life. After 4 hours of procedure, we ended with the removal of $18 \mathrm{~kg}$ of the right breast and $14 \mathrm{~kg}$ of the left breast, making a total of $32 \mathrm{~kg}$ of breast pieces. We can observe the reduction of the layers seen on the back (Figure 3 and Figure 4). Some photos were not found or we did not think it was due to the impossibility of identification due to the number of overlapping layers. The preoperative and postoperative periods 


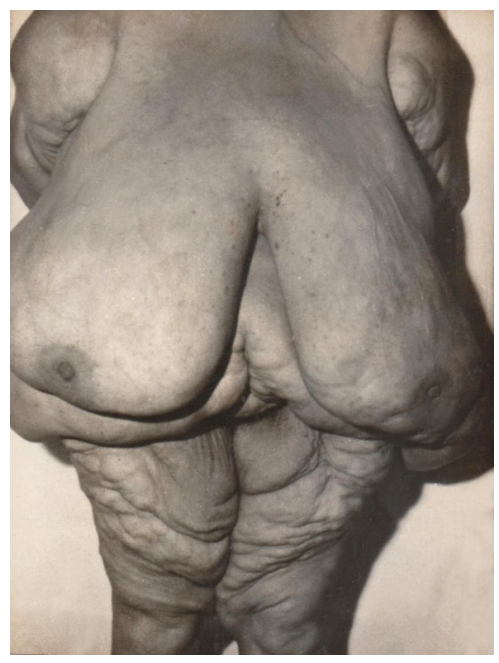

Figure 2. Preoperative of the breasts (2 layers).

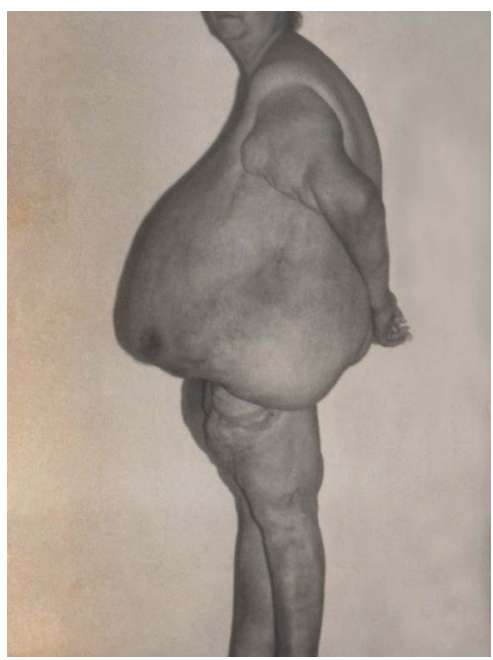

Figure 3. Preoperative profile after 1st weight loss.

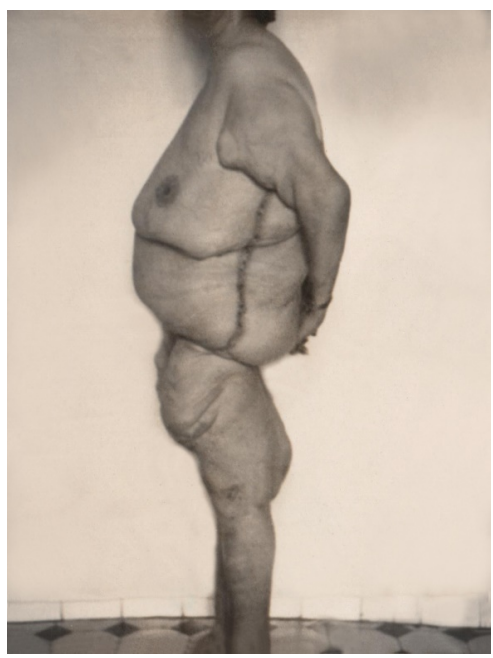

Figure 4. Postoperative of the 1st breast surgery and postoperative with 4 days of longitudinal abdominal surgery. 
went smoothly, having been assisted by 4 surgeons and 3 anesthetists. After 6 months, we studied and performed the second surgical intervention, the first to remove the abdomen. When we put the patient on the table, the anesthetist said: "Dr. José Humberto, the belly fell to the sides of the table". Thus, we concluded that, as it was relief surgery, but not yet described in the literature, we decided to make the longitudinal surgical incision, which started in the armpit and ended near the pelvic region (Figures 5-7). At the end of this surgical time, she had her only cardiac arrest for 3 years, which was soon reversed. Six months later, we performed the second repair of the breasts and, with an interval of 3 months, we performed the second abdominal repair, with a transverse incision. Also in the 2nd year of hospitalization, we underwent surgery on the thighs and the pubic mound (Figure 8 and Figure 9). In the last six months of the 3rd year of hospitalization, we performed the last surgeries to decrease the diameter of the arms (Figure 10 and Figure 11). For the purpose of comparing pre and postoperative periods, at the end of the 3 years, we show the result (Figure 12 and Figure 13). The patient arrived weighing $210 \mathrm{~kg}$ and was discharged with $71 \mathrm{~kg}$. She arrived wearing a giant dress, which fit 4 people inside (Figure 14), and was discharged wearing "jeans" and mid-heel shoes [8]. It is worth remembering that, at that time, we did not have a bibliographic review that would assist us in choosing the technique. For this reason, we chose linear incisions with the intention of "body relief" [9] [10] for the patient.

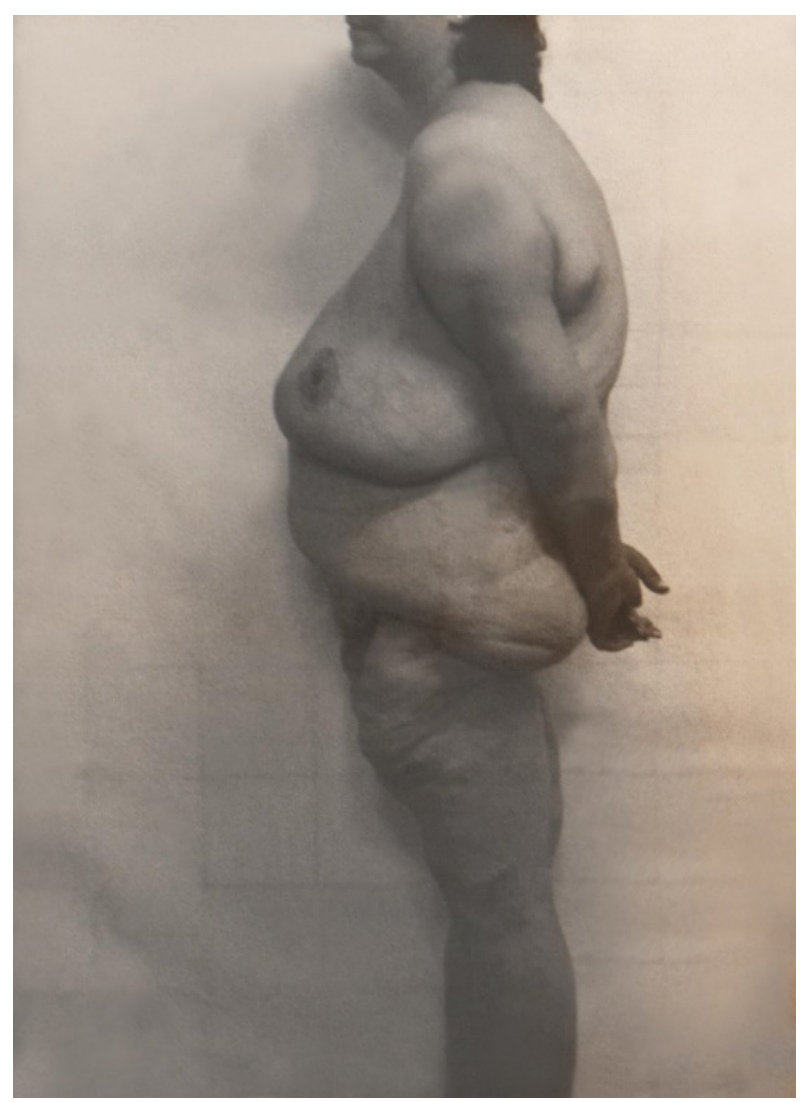

Figure 5. Postoperative profile at 6 months. 


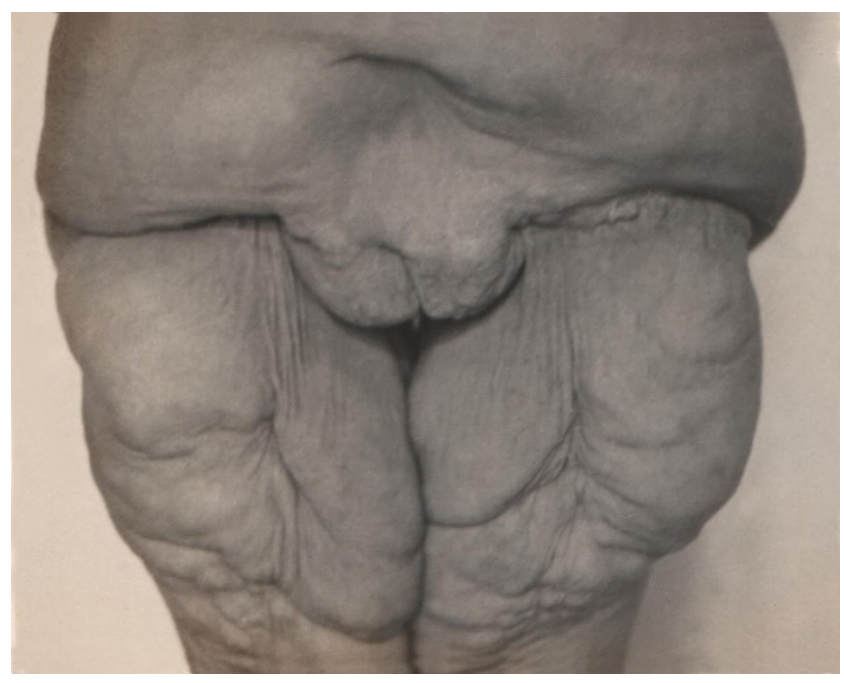

Figure 6. Preoperative of thighs and pubic mount.

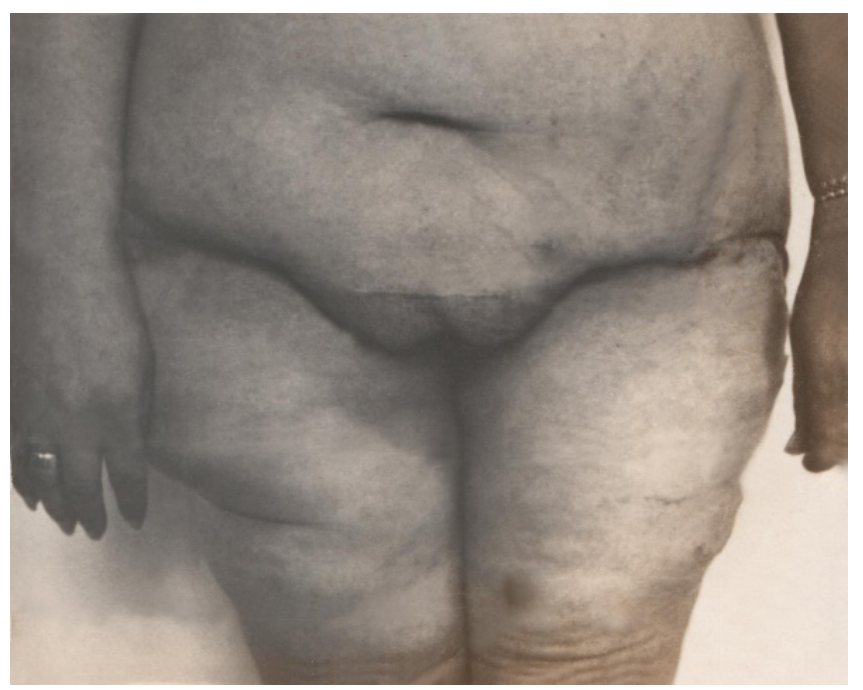

Figure 7. Postoperative of thighs and pubic mount and abdominal postoperative with transverse incision.

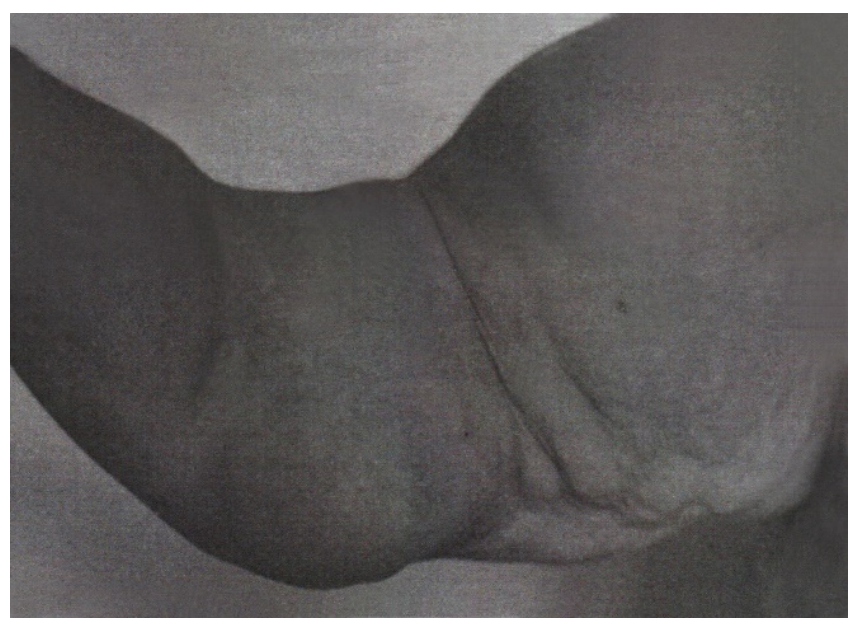

Figure 8. Preoperative arm. 


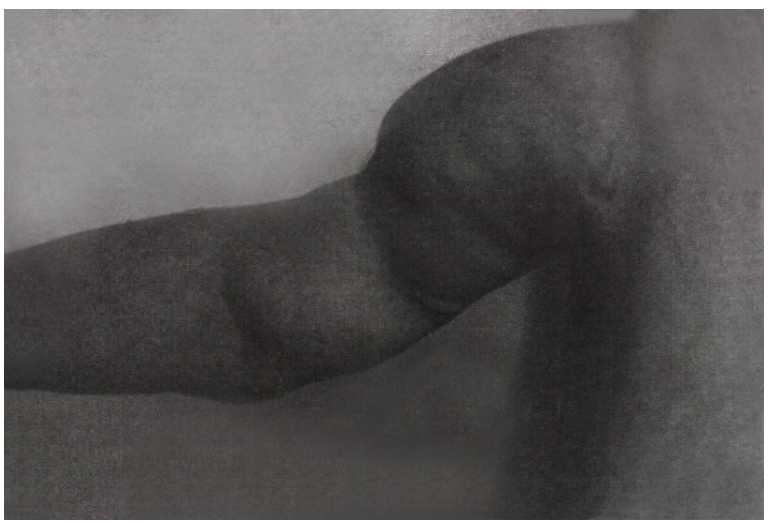

Figure 9. Postoperative arm.

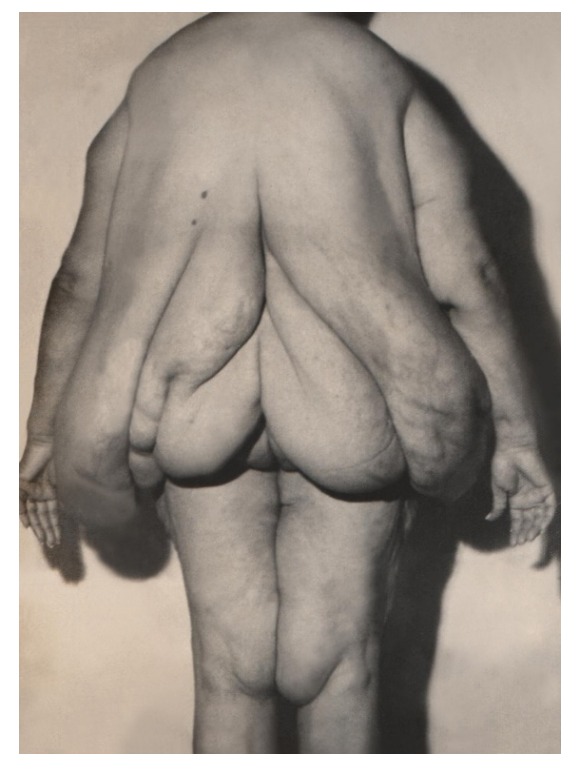

Figure 10. Preoperative of the back.

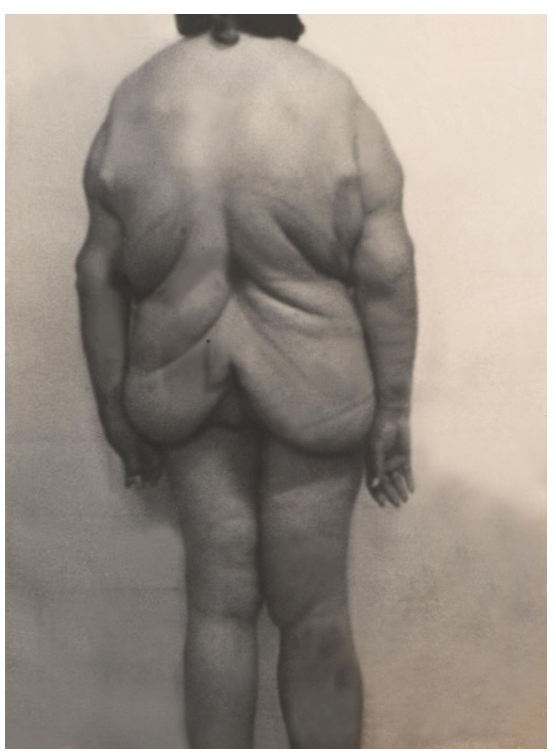

Figure 11. Post-operative of the back after the 1st surgery of the breasts and abdomen. 


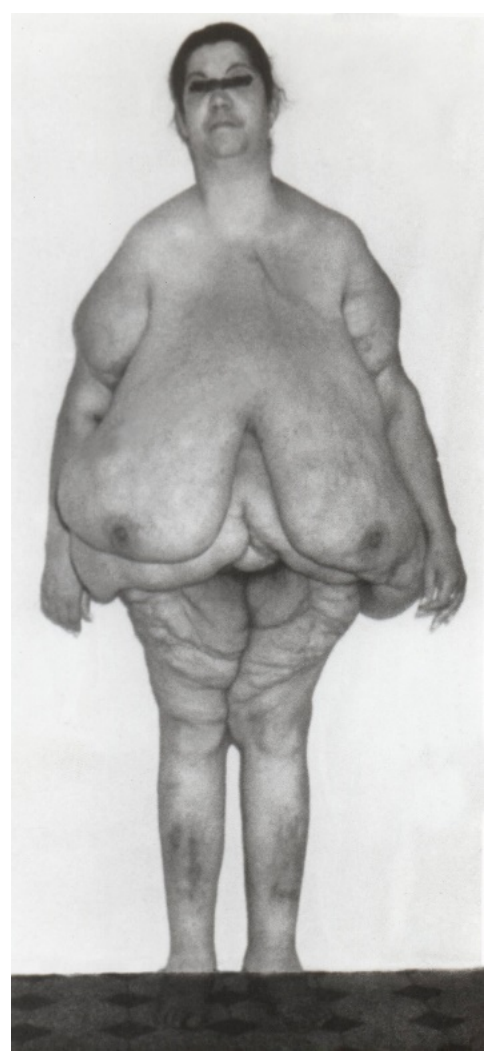

Figure 12. Preoperative of the 1st surgery. Hospitalization-210 kg.

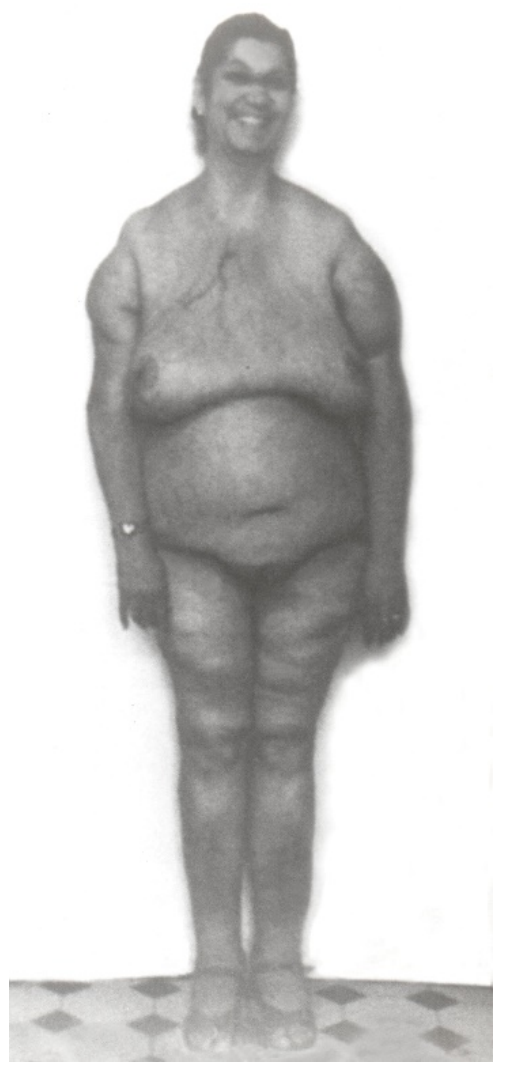

Figure 13. Last postoperative of the 9 reparative surgeries performed. High-71 kg. 


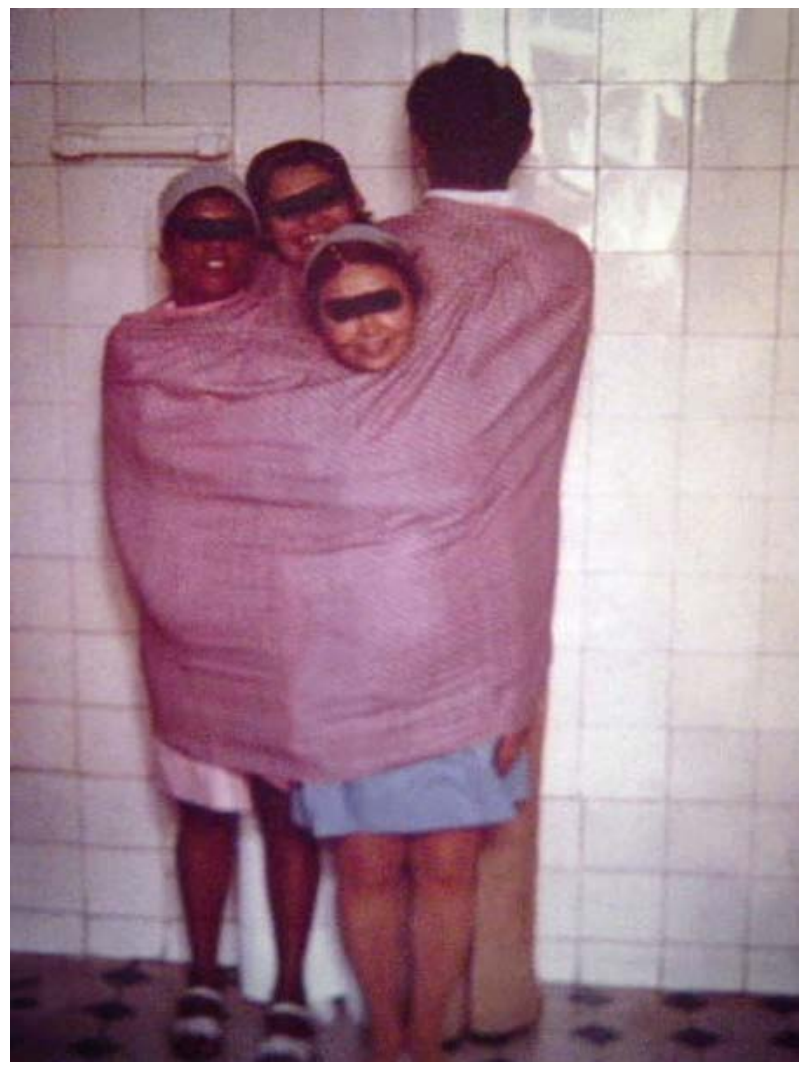

Figure 14. Dress worn on the 1st admission (4 people inside).

\section{Discussion}

Perhaps today, after the bodily relief of the breasts, I would recommend bariatric surgery, even though I know that weight loss depends on a great psychological preparation, because when they are slowly monitored they are more advantageous. We have already published several articles on the subject, but even so, there is a large population increase at the moment. Recalling this case report will serve to open doors for more publications and awaken young doctors to this specialty that covers cases like this, which, one day, will be considered public health. Saying that there is nothing to do is an easy solution. It was difficult to face the case, with no future perspective and uncertain results. Even today, after 45 years, we still consider it a complicated case, but one that could not be ignored in view of the patient's age and the psychological severity she was experiencing. We always respect different or even contrary opinions. Today, perhaps, the postoperative results could be more acceptable; however what we achieved was the best for that moment or that time.

In this reported case, we had to develop a solution taking into account the patient's age, 41, her willingness to live and finish raising her children. It was not a common case and we did not have many resources at the time. Despite numerous opinions from more experienced teams, none of them gave us plausible alternatives. The idea of remembering the case came with the interest of encouraging younger specialist doctors to have the courage to help others even know- 
ing the risks and the uncertain outcome. Discernment and dedication in hard times, using common sense, respecting science and having faith will provide a better result. A hypertensive and diabetic woman who was discharged with all normal laboratory tests [11].

\section{Conclusion}

As professionals and as human beings, we are very happy to see the result of this reported case. Monitoring and being part of this process, from the arrival of patient I. S., weighing $210 \mathrm{~kg}$, carried by relatives, until being discharged, wearing jeans and $71 \mathrm{~kg}$ is the real payment for the well being provided to her. Seeing a person suffering from hypertension, arriving with $310 \mathrm{mg} / \mathrm{dL}$ of blood glucose and blood pressure $170 \times 110 \mathrm{mmHg}$, leaving the hospital with $90 \mathrm{mg} / \mathrm{dL}$ of blood glucose and $130 \times 80 \mathrm{mmHg}$ of blood pressure is the best final balance we could have obtained, giving us the certainty, it was worth it! At that time, we still did not have the collaboration of bariatric surgery or liposuction (1980) [12]. The doors will always be open for us to evolve and, certainly, with the appearance of many new techniques for improvements in all specialties. It is important to remember that 9 surgical acts were performed, without bariatric and without liposuction, which would have contributed a lot. The best gratitude was to witness the degree of joy, satisfaction of the patient and the social inclusion that we felt during the ultimate discharge.

\section{Conflicts of Interest}

The authors declare no conflicts of interest regarding the publication of this paper.

\section{References}

[1] Scherer, P. and Santos, A. (2012) Weight That Is Not Measured on the Scale: The Repercussions of Obesity on the Subjects' Daily Lives. Masters Dissertation, Pontifical Catholic University, Rio Grande do Sul, Brazil. http://hdl.handle.net/10923/5192

[2] Resende, J.H.C., de Moura, Á.I., Mariano, A.C.A., Silva, H.K., Silva, H.L., Campos, I.A., de Lima, L.C.F., Gabriel, M.B. and Silverio, W.O. (2019) Gigantomasty in Female Workers: "Public Health Cases". Modern Plastic Surgery, 9, 1-7. https://doi.org/10.4236/mps.2019.91001

[3] De Carvalho, P.S., et al. (2007) Bariatric Surgery Cures Metabolic Syndrome? Arquivos Brasileiros de Endocrinologia e Metabologia, São Paulo, 51, 79-85. http://www.scielo.br/scielo.php?script=sci_arttext\&pid=S0004-27302007000100013 \&lng=en\&nrm=iso

[4] Medeiros, B., et al. (2018) The Importance of Accessibility in Organizations. Proceedings of the VI Scientific Day of Campos Gerais in Ponta Grossa, Paraná, 24 September 2018, Poster. Edition v. 16. https://www.iessa.edu.br/revista/index.php/jornada/article/view/684

[5] Ministry of Health (2008) Bariatric Surgery in the Treatment of Morbid Obesity. Brazilian Health Technology Assessment Bulletin, III. 
https://www.google.com/url?sa=t\&rct=j\&q=\&esrc=s\&source=web\&cd=1\&ved=2ah UKEwjMzvSbnPDoAhXsH7kGHRIPDIYQFjAAegQIAhAB\&url=http\%3A\%2F\%2F www.rebrats.saude.gov.br\%2Finstitucional\%2Fbrats\%3Fdownload\%3D104\%3An-0 5-cirurgia-bariatrica-no-tratamento-da-obsidade-morbida\&usg=AOvVaw0FMS6K hv4gkl9oIm0bfWpq

[6] Rocha, L.J.L.F., De Vilhena, J. and De Vilhena Novaes, J. (2009) Morbid Obesity: When Eating Goes far Beyond Food. Psicologia em Revista, Belo Horizonte, 15, 77-96.

http://pepsic.bvsalud.org/scielo.php?script=sci_arttext\&pid=S1677-11682009000200 006\&lng=pt\&nrm=iso

[7] Younis, F., et al. (2020) Endoscopic Treatment of Early Leaks and Strictures after Laparoscopic One Anastomosis Gastric Bypass. BMC Surgery, 20, 33.

https://doi.org/10.1186/s12893-020-0686-2

[8] Paul, M.A., Opyrchał, J., Knakiewicz, M., Jaremków, P., Duda-Barcik, Ł., Ibrahim, A.M.S., et al. (2020) The Long-Term Effect of Body Contouring Procedures on the Quality of Life in Morbidly Obese Patients after Bariatric Surgery. PLOS ONE, 15, e0229138. https://doi.org/10.1371/journal.pone.0229138

[9] Resende, J.H.C. (2003) Gigantomastia. In: Plastic Surgery-Fundamentals and Art-Aesthetic Surgery, MEDSI, São Paulo, Vol. 1, 555-561.

[10] Resende, J.H.C. (2008) Resende's Technique for Correcting Gigantomastia-Body Relief Surgery, Treated Plastic Surgery in Obesity. Rubio, Rio de Janeiro, 357-365.

[11] Robles-Cervantes, J.A., Yanes-Dias, S., Cardenas-Cama-Rena, L. (2004) Modification of Insulin, Glucose and Cholesterol Levels in Nonobese Women Undergoing Liposuction: Is Liposuction Metabolically Safe? Annals of Plastic Surgery, 52, 64-67. https://doi.org/10.1097/01.sap.0000096448.59407.43

[12] Hong, Y.G., Kim, H.T., Seo, S.W., et al. (2006) Impact of Large-Volume Liposuction on Serum Lipids in Orientals: A Pilot Study. Aesthetic Plastic Surgery, 30, 327-332. https://doi.org/10.1007/s00266-005-0010-7 